\title{
Evaluation of Hungarian Sporthorse mare performance tests
}

\author{
János Posta - István Komlósi - Sándor Mihók \\ University of Debrecen, Centre of Agricultural and Applied Economic Sciences, Institute of Animal Sciences, \\ H-4032 Debrecen Böszörményi 138., postaj@agr.unideb.hu
}

Keywords: horse breeding, sport horse, breeding value, selection index

\section{SUMMARY}

Results of the Hungarian Sporthorse mare performance tests were evaluated. Data from the period of 1993-2009 were used, covering scores of 618 3-year-old and 310 4-year-old mares, 109 of them were tested at both ages. Seventeen traits were scored on the tests, which covered ten conformational, three free jumping performance and four movement analyses traits, respectively. Breeding value estimation was based on BLUP animal model. Test year, age and owner were included in the model as fixed effects. Variance components were estimated with VCE-6 software package. Heritabilities ranged from 0.32 (frame) to 0.50 (saddle region) for conformation traits, from 0.39 (jumping style) to 0.49 (jumping ability and jumping skill) for free jumping traits and from 0.20 (walk) to 0.48 (canter) for movement analysis traits. Breeding value indexes were constructed for each trait group. Conformation index was computed based on the weighted scores of the breeding values of conformational traits. The conformational score scales were used as weightings. Free jumping and movement indexes contain the proper breeding values with equal weights. A total index was also constructed using conformation index, two times the free jumping index and two times the movement index. Each breeding values and breeding value indexes were presented with the mean 100 and standard deviation of 20 for the easier understanding.

\section{INTRODUCTION}

The BLUP method was used first by Árnason (1980) in horse breeding for Icelandic Toelter horses. Utilization of this method spread very quickly. Tavernier (1988) wrote about the application of BLUP procedures in France and there was some information from the Swedish adaptation in Philipsson's (2005) study. A German breeding estimation method developed by Meinardus (1988) is based on show jumping and dressage results. The results of further German works and developments for estimation methods can be found in LührsBehnke et al. (2005) and Velsen-Zerweck - Bruns (1998) studies. Importance of performance tests and possible utilization of its results are also reported by Lewczuk et al. (2004ab).

For the improvement of breeding value estimation in Hungary, the application and correction (if it is necessary) of widely used methods is needed. Preliminary analysis of Hungarian Sporthorse performance data were done by Posta et al. (2007). Our analysis was done in correspondence with The Association of Hungarian Horse Breeders and Horse Organization and The Association of Hungarian Sporthorse Breeders (MSLT). The aims of the study were breeding value estimation and construction of breeding value indexes for the evaluated traits in the performance test of Hungarian Sporthorse mares

\section{MATERIALS AND METHODS}

The data set used for the analysis was supplied by MSLT. Test records of three-year-old and four-year-old mares from 1993 to 2009 were analyzed. There were 593 records from 3-year-old and 299 records from 4-yearold mares, respectively. One hundred-nine mares were tested at both ages.

The mare performance test consists of conformation judgement, free jumping and movement analysis.

Traits judged at mare performance test:

Conformation traits: type, head, neck, saddle region, frame, forelimbs, hind limbs, regulatory of movement, impulsion and elasticity of movement, overall impression.

Free jumping: jumping style, jumping ability-sense of distance; jumping skill.

Movement analysis: walk, trot, canter, overall impression. (MSLT, 2006)

The scores of free jumping and movement analysis traits were scored between 0 and 10 . Conformation traits were judged by weighting the riding horse qualities since 2000 . Weighted traits (neck, forelimbs, hind limbs and impulsion and elasticity of movement) were scored in a 0-12 scale. Type (0-6), head and frame (0-8) were judged in a smaller interval. Other conformational traits were scored between 0 and 10 . All traits were judged by a committee and the horse gets the mean of the scores of the committee members. The final score of mare test contains the mean of the conformation score, the mean of free jumping performance scores and the mean of movement analysis scores multiplied by 1, 2, and 2, respectively (MSLT, 2006).

The pedigree used for the analysis contained ancestors of participating mares at least 2 generations back. Variance components and heritabilities were taken using VCE-6 (Groeneveld et al., 2008) breeding values were estimated with PEST (Groeneveld et al., 1990) for each trait using the following model: $Y_{i j k l m}=\mu+$ Year $_{i}+$ Age $_{j}+$ Owner $_{k}+$ Animal $_{l}+e_{i j k l m}$

where $\mathrm{Y}_{\mathrm{ijklm}}=\mathrm{m}$-th score of 1.-th mare; $\mu=$ the population mean; Year ${ }_{\mathrm{i}}=$ effect of mare test's year (19932009); Age $_{\mathrm{j}}=$ effect of age class $(3,4) ;$ Owner $_{\mathrm{k}}=$ effect of owner; Animal $_{1}=$ random effect of l-th mare; $\mathrm{e}_{\mathrm{ijklm}}=$ random residual term.

Including the breeder in the model made no significant improvement, so its inclusion was not necessary. 
Breeding values were presented with the mean 100 and standard deviation of 20 Koenen [2005] using the formula:

$$
E B V_{p}=100+\left(\left(E B V_{u}-\text { mean }_{u}\right) / \sigma_{u}\right) * 20,
$$

where $\mathrm{EBV}_{\mathrm{p}}$ is the estimated $\mathrm{BV}$ on the publication scale; $\mathrm{EBV}_{\mathrm{u}}$ is the estimated $\mathrm{BV}$ on the original scale; meanu is the mean estimated $\mathrm{BV}$ on the original scale of the population and $\sigma \mathrm{u}$ is the standard deviation of estimated BV on the original scale of the population.

Reliability was computed based on the estimated error variance for every trait in the case of each animal using the following formula:

$$
r=\sqrt{1-P E V / \sigma_{a}^{2}}
$$

where $r$ is the correlation between the estimated and true genetic value; PEV is the predicted error variance of the breeding value and $\sigma_{\mathrm{a}}{ }^{2}$ is the genetic variance of the measured trait.

\section{RESULTS AND DISCUSSION}

Means and standard deviations for the traits scored in the performance test are given in Table 1. Differences in the number of horses between different trait groups are due to the fact that some horses did not complete all of the tests.

Table 1.

\begin{tabular}{|c|c|c|c|c|c|c|c|c|c|c|}
\hline \multirow{2}{*}{ Trait } & \multicolumn{2}{|c|}{$\begin{array}{c}\text { Number of } \\
\text { horses }\end{array}$} & \multicolumn{2}{|c|}{ Mean } & \multicolumn{2}{|c|}{ Standard deviation } & \multicolumn{2}{|c|}{ Minimum } & \multicolumn{2}{|c|}{ Maximum } \\
\hline & $\begin{array}{c}3 \text { year } \\
\text { old }\end{array}$ & $\begin{array}{c}4 \text { year } \\
\text { old }\end{array}$ & $\begin{array}{c}3 \text { year } \\
\text { old }\end{array}$ & $\begin{array}{c}4 \text { year } \\
\text { old }\end{array}$ & $\begin{array}{c}3 \text { year } \\
\text { old }\end{array}$ & $\begin{array}{c}4 \text { year } \\
\text { old }\end{array}$ & $\begin{array}{c}3 \text { year } \\
\text { old }\end{array}$ & $\begin{array}{c}4 \text { year } \\
\text { old }\end{array}$ & $\begin{array}{c}3 \text { year } \\
\text { old }\end{array}$ & $\begin{array}{c}4 \text { year } \\
\text { old }\end{array}$ \\
\hline Type & 593 & 299 & 4.80 & 4.78 & 0.798 & 0.822 & 3 & 2.4 & 6 & 6 \\
\hline Head & 593 & 299 & 6.34 & 6.37 & 0.904 & 0.949 & 3.2 & 4 & 8 & 8 \\
\hline Neck & 593 & 299 & 8.45 & 8.38 & 1.185 & 1.176 & 6 & 4.8 & 12 & 11 \\
\hline Saddle region & 593 & 299 & 7.70 & 7.57 & 1.087 & 1.076 & 4 & 4 & 10 & 10 \\
\hline Frame & 593 & 299 & 6.33 & 6.31 & 0.964 & 1.066 & 4 & 3 & 9 & 10 \\
\hline Forelimbs & 593 & 299 & 8.32 & 8.18 & 1.090 & 1.078 & 4.8 & 4.8 & 11 & 11 \\
\hline Hind limbs & 593 & 299 & 7.99 & 7.91 & 1.129 & 1.174 & 3.6 & 4.8 & 11 & 11 \\
\hline Regularity of movement & 593 & 299 & 7.49 & 7.51 & 1.005 & 1.012 & 4 & 5 & 10 & 10 \\
\hline Impulsion and elasticity of movement & 593 & 299 & 7.92 & 7.73 & 1.423 & 1.370 & 4 & 1.2 & 12 & 11 \\
\hline Overall impression & 593 & 299 & 7.20 & 7.09 & 0.943 & 0.908 & 4.5 & 5 & 9.7 & 9.8 \\
\hline Jumping style & 576 & 295 & 7.16 & 7.34 & 0.993 & 1.117 & 4 & 4 & 10 & 10 \\
\hline Jumping ability-sense of distance & 576 & 295 & 7.23 & 7.52 & 1.140 & 1.251 & 3.3 & 4 & 10 & 10 \\
\hline Jumping skill & 174 & 62 & 7.39 & 7.62 & 1.095 & 1.271 & 4 & 5 & 10 & 10 \\
\hline Walk & 578 & 295 & 6.86 & 6.83 & 0.988 & 1.038 & 3 & 4 & 9.1 & 9 \\
\hline Trot & 578 & 295 & 6.40 & 6.41 & 0.842 & 0.808 & 3 & 4 & 9.1 & 8.5 \\
\hline Canter & 578 & 295 & 6.86 & 6.98 & 0.958 & 0.910 & 4 & 4 & 10 & 9 \\
\hline Overall impression & 578 & 295 & 6.93 & 6.97 & 0.844 & 0.859 & 4 & 3 & 9.6 & 9 \\
\hline
\end{tabular}
Number, mean, standard deviation, minimum and maximum values of horses participating in self performance test as 3 and 4 years

Table 2.

Estimated heritabilities of traits judged at Hungarian mare performance tests

\begin{tabular}{lcc}
\hline Trait & $\mathrm{h}^{2}$ & $\begin{array}{c}\text { standard error } \\
\text { of } \mathrm{h}^{2}\end{array}$ \\
\hline Type & 0.41 & 0.08 \\
Head & 0.47 & 0.07 \\
Neck & 0.36 & 0.08 \\
Saddle region & 0.50 & 0.07 \\
Frame & 0.32 & 0.09 \\
Forelimbs & 0.32 & 0.10 \\
Hind limbs & 0.33 & 0.09 \\
Regularity of movement & 0.36 & 0.09 \\
Impulsion and elasticity of movement & 0.44 & 0.07 \\
Overall impression & 0.40 & 0.08 \\
\hline Jumping style & 0.39 & 0.09 \\
Jumping ability-sense of distance & 0.49 & 0.08 \\
Jumping skill & 0.49 & 0.14 \\
\hline Walk & 0.20 & 0.10 \\
Trot & 0.34 & 0.08 \\
Canter & 0.48 & 0.08 \\
Overall impression & 0.24 & 0.08 \\
\hline
\end{tabular}

Heritabilities of individual traits were moderate to high as shown in Table 2. Estimated heritabilities were in the range of 0.32 (neck) and 0.50 (saddle region), 0.39 (jumping style) and 0.49 (both jumping skill and jumping 
ability) and 0.20 (walk) and 0.48 (canter) for conformational traits, free jumping traits and movement analysis traits, respectively.

Estimated heritabilities for some conformational traits were higher than that presented by Hartmann (1999) (traits were: type, head, neck, forelimbs, hind limbs) or Nissen (1997) (traits were: type, forelimbs, hind limbs). For movement analysis traits comparing estimated heritabilities (Table 2), there were similar results for walk $\left(h^{2}=0.22\right)$, but greater values for trot and canter than estimated by Huizinga et al. (1990). The heritabilities in this study were similar to the heritability estimates for walk and trot given by Luehrs-Behnke et al. (2002).

As a result of discussions with sport horse breeders, there was a demand to construct breeding value indexes to sum the estimated breeding values (EBV) of the evaluated traits. A Conformation Index was developed to summarize the EBVs of the ten conformational traits (Figure 1.). As the traits are thought not be equally important for a riding horse, some trait were weighted in the index. The weights of each trait were the same as the maximum point of the trait.

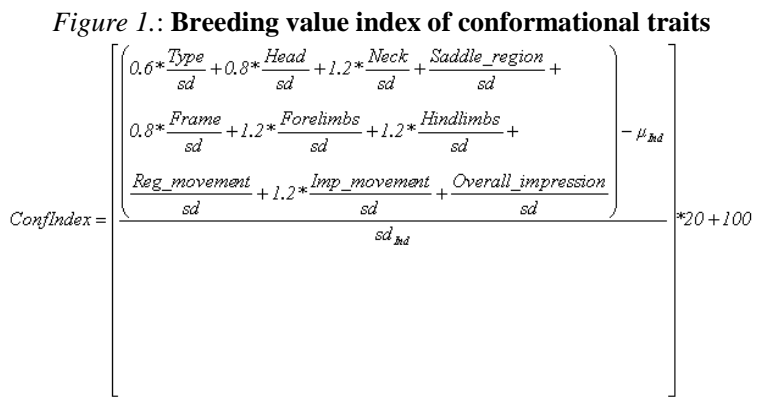

\begin{tabular}{|c|c|c|c|}
\hline ConfIndex & Conformational Index & & \\
\hline Type & Type & $\mathrm{sd}=$ & 0.145 \\
\hline Head & Head & $\mathrm{sd}=$ & 0.204 \\
\hline Neck & Neck & $\mathrm{sd}=$ & 0.244 \\
\hline Saddle_region & Saddle region & $\mathrm{sd}=$ & 0.280 \\
\hline Frame & Frame & $s d=$ & 0.148 \\
\hline Forelimbs & Forelegs & $\mathrm{sd}=$ & 0.182 \\
\hline Hindlimbs & Hind legs & $\mathrm{sd}=$ & 0.208 \\
\hline Reg_movement & Regularity of movement & $\mathrm{sd}=$ & 0.161 \\
\hline Imp_movement & Impulsion and elasticity of movement & $\mathrm{sd}=$ & 0.316 \\
\hline Overall_impression & Overall impression - conformation & $\mathrm{sd}=$ & 0.197 \\
\hline$\mu_{\text {Ind }}$ & Mean of Conformational Index & $\mathrm{av}=$ & 0.651 \\
\hline $\operatorname{sd}_{\text {Ind }}$ & Standard deviation of Conformational Index & $\mathrm{sd}=$ & 7.198 \\
\hline
\end{tabular}

The four movement analysis traits were scored on the same scale, so they were inserted into the Movement Index with equal weights (Figure 2.).

Figure 2.: Breeding value index of movement analysis traits

where:

MovementIndex

Walk

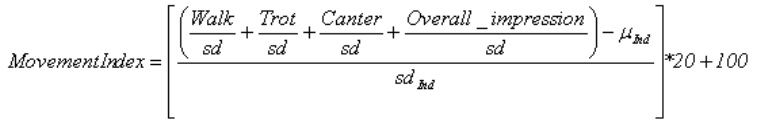

Trot

Canter

Overall_impression

$\mu_{\text {Ind }}$

$\mathrm{sd}_{\text {Ind }}$

Movement Analysis Index

Walk

Trot

Canter

Overall impression

Mean of Movement Analysis Index

Standard deviation of Movement Analysis Index

$\begin{array}{ll}\mathrm{sd}= & 0,103 \\ \mathrm{sd}= & 0,154 \\ \mathrm{sd}= & 0,223 \\ \mathrm{sd}= & 0,112 \\ \mathrm{av}= & 0.417 \\ \mathrm{sd}= & 3.225\end{array}$

Figure 3.: Breeding value index of free jumping traits

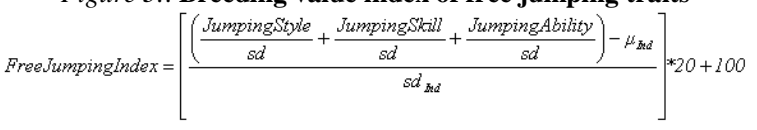

where:

FreeJumpingIndex $\quad$ Free Jumping Index

JumpingStyle Jumping style

JumpingSkill Jumping skill

JumpingAbility Jumping ability

$\mu_{\text {Ind }}$

Mean of Free Jumping Index

$\mathrm{sd}_{\text {Ind }}$

Standard deviation of Free Jumping Index

$\begin{array}{ll}\mathrm{sd}= & 0,216 \\ \mathrm{sd}= & 0,287 \\ \mathrm{sd}= & 0,148 \\ \mathrm{av}= & 0.207 \\ \mathrm{sd}= & 2.541\end{array}$


Free jumping Index was constructed similarly; the three free jumping performance traits were used with equal weights in the index (Figure 3.). Furthermore, an overall index was also developed based on the three indexes mentioned above. The members of the index were weighted based on the regulation of the Breeder Association (Figure 4.).

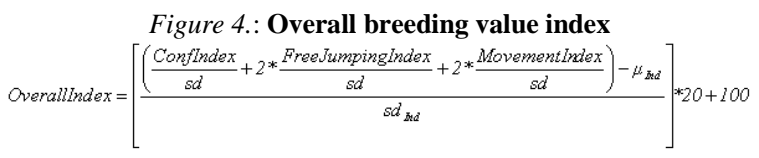

where:

\section{OverallIndex Overall Index}

ConfIndex

FreeJumpingIndex

MovementIndex

Conformational Index

Free Jumping Index

Movement Analysis Index

Mean of Overall Index

$\operatorname{sd}_{\text {Ind }}$

Standard deviation of Overall Index

$\begin{array}{ll}\mathrm{sd}= & 7.198 \\ \mathrm{sd}= & 2.541 \\ \mathrm{sd}= & 3.225 \\ \mathrm{av}= & 0.512 \\ \mathrm{sd}= & 3.854\end{array}$

Each index was presented (similarly to the breeding values) following the Interstallion recommendations (Koenen, 2005) with the mean 100 and standard deviation of 20 (Figure 5.).

Figure 5.: Breeding values and breeding value indexes of stallion with the most daughters participating in mare performance tests 2533 Goliath (32 daughters)

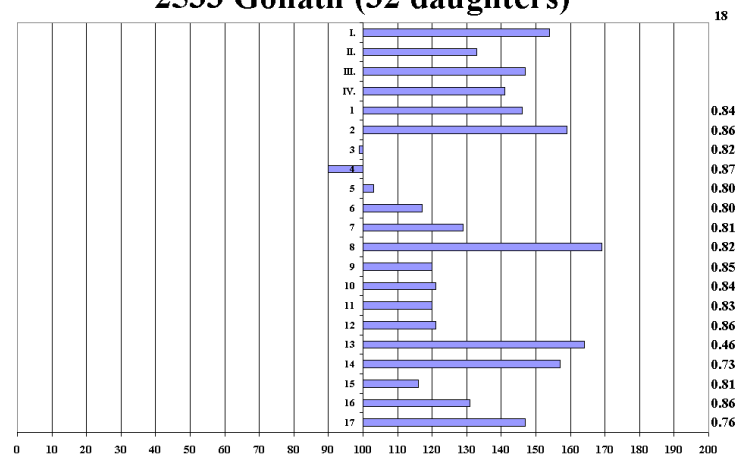

I.: Overall Index, II.: Conformational Index, III.: Free Jumping Index, IV.: Movement Analysis Index, 1: Type, 2: Head, 3: Neck, 4: Saddle region, 5: Frame, 6: Forelimbs, 7: Hindlimbs, 8: Regularity of movement, 9: Impulsion and elasticity of movement, 10: Overall impression, 11: Jumping style, 12: Jumping skill, 13: Jumping ability, 14: Walk, 15: Trot, 16: Canter, 17: Overall impression, 18: Reliability

The reliability of the estimated breeding values is also shown for each trait. The stallion "Goliath" seems to be an overall positive stallion, because its breeding value indexes are more than one standard deviation above the overall mean (100) of the stock. It is important to emphasize that notable progress could be expected in a trait only with the preference of stallions (and offspring of these stallions) whose breeding values approximate to the three standard deviation, but at least one standard deviation greater than the population mean. The reliability values were above 0.7 for almost each trait. 'Jumping ability' was scored only for the last four years this might cause the lower reliability value. To improve the reliability of the estimated breeding values, the evaluation of more offspring would be necessary in the performance tests.

\section{REFERENCES}

ÁRNASON TH. (1980): Genetic studies on the Icelandic Toelter-horse (estimation of breeding values). Paper presented at the 31 st Annual Meeting of the European Association for Animal Production, 1980. szeptember 1-4. Commission on Horse Production, Munich, Germany. p. 5.

GROENEVELD E., KOVAC M., WANG T. (1990): PEST, a general purpose BLUP package for multivariate prediction and estimation. In. 4th World Congress on Genetics Applied to Livestock Production, Edinburgh, 488-491, No. XIII.

GROENEVELD E., KOVAC M., MIELENZ M. (2008): VCE User's Guide and Reference Manual Version 6.0, Institute of Farm Animal Genetics Friedrich Loeffler Institute (FLI), Neustadt, Germany

HARTMANN O. (1999): Untersuchungen zur Anwendung der linearen Beschreibung in der Reitpferdezucht. Otto Hartmann - Berlin: Logos-Verlag

HUIZINGA H.A., BOUKAMP M., SMOLDERS G. (1990): Estimated parameters of field performance testing of mares from the Dutch Warmblood riding horse population. Livestock Production Science 26, 291-299

KOENEN E. (2005): Publication of breeding values; Interstallion Workshop „Use of genetic evaluations in sport horse breeding” September 5-6. 2005. 
LEWCZUK D., SZARSKA E., PIETRZAK S. (2004a): An attempt at objectivization the stallion's performance test in Poland. Part I - 8 month test. Animal Science Papers and Reports 3, 287-296.

LEWCZUK D., SZARSKA E., STRZELEC K., PIETRZAK S. (2004b): An attempt at objectivization the stallion's performance test in Poland. Part II - 100-days test. Animal Science Papers and Reports 4, 645-652.

LUEHRS-BEHNKE H., ROECHE R., KALM E. (2002): Genetic associations among traits of the new integrated breeding evaluation method used for selection of German Warmblood Horses. Veterinarija ir Zootechnika 18 (40), 90-93

LÜHRS-BEHNKE H., RÖHE R., KALM E. (2005): Beziehungen zwischen Merkmalen der Stuten- und Hengstprüfung und Prüfungsklassen des Turniersports 4. Pferde-Workshop, Uelzen, February 22-23. 2005. 55-60.

MEINARDUS H. (1988): Züchterische Nutzung der Turniersportprüfung für Reitpferde; Göttingen

MSLT (2006): A Magyar Sportlótenyésztők Országos Egyesületének Tenyésztési Szabályzata (Breeding Regulations of the Association of Hungarian Sporthorse Breeders) In Hungarian.

NISSEN T. (1997): Kanca teljesítmény-vizsgák gyakorlati tapasztalatai Schleswig-Holsteinben. DATE Állattenyésztési Napok.

Nemzetközi Lótenyésztési Tanácskozás. Debreceni Agrártudományi Egyetem Kiadványa, pp. 53-67.

PHILIPSSON J. (2005): Importance of young horse testing for genetic evaluations in Sweden, 4. Pferde-Workshop, Uelzen, February 22-23. 2005. 41-45.

Posta J., Komlósi I., Mihók S. (2007): Principal component analysis of performance test traits in Hungarian Sporthorse mares. Archiv für Tierzucht 50. 2007 125-135 p.

TAVERNIER A. (1988): Advantages of BLUP animal model for breeding value estimation in horses; Livestock Production Science 20: $149-160$

VELSEN-ZERWERK A.v., BRUNS E. (1998): Integrierte Zuchtwertschätzung unter Nutzung der Ergebnisse der Hengstleistungsund Zuchtstutenprüfungen. 2. Pferde-Workshop Uelzen - Aktuelle Fragen der Reitpferdezucht, Institut für Tierzcht und Tierhaltung der Universität Kiel, 1998. P. 41-48. 